\title{
The Genome Sequence of the Gram-Positive Sugarcane Pathogen Leifsonia xyli subsp. xyli
}

Claudia B. Monteiro-Vitorello, ${ }^{1}$ Luis E. A. Camargo, ${ }^{1}$ Marie A. Van Sluys, ${ }^{2}$ João P. Kitajima, ${ }^{3}$ Daniela Truffi, ${ }^{1}$ Alexandre M. do Amaral, ${ }^{4}$ Ricardo Harakava, ${ }^{5}$ Julio C. F. de Oliveira, ${ }^{6}$ Derek Wood, ${ }^{7}$ Mariana C. de Oliveira, ${ }^{2}$ Cristina Miyaki, ${ }^{2}$ Marco A. Takita, ${ }^{8}$ Ana C. R. da Silva, ${ }^{3,9}$ Luis R. Furlan, ${ }^{10}$ Dirce M. Carraro, ${ }^{11}$ Giovana Camarotte, ${ }^{3}$ Nalvo F. Almeida, Jr., ${ }^{12}$ Helaine Carrer, ${ }^{1}$ Luiz L. Coutinho, ${ }^{1}$ Hamza A. El-Dorry, ${ }^{9}$ Maria I. T. Ferro, ${ }^{6}$ Paulo R. Gagliardi, ${ }^{1}$ Eder Giglioti, ${ }^{13}$ Maria H. S. Goldman, ${ }^{14}$ Gustavo H. Goldman, ${ }^{15}$ Edna T. Kimura, ${ }^{16}$ Emer S. Ferro, ${ }^{16}$ Eiko E. Kuramae, ${ }^{10}$ Eliana G. M. Lemos, ${ }^{6}$ Manoel V. F. Lemos, ${ }^{6}$ Sonia M. Z. Mauro, ${ }^{6}$ Marcos A. Machado, ${ }^{8}$ Celso L. Marino, ${ }^{17}$ Carlos F. Menck, ${ }^{16}$ Luiz R. Nunes, ${ }^{18}$ Regina C. Oliveira, ${ }^{18}$ Gonçalo G. Pereira, ${ }^{19}$ Walter Siqueira, ${ }^{20}$ Alessandra A. de Souza, ${ }^{4}$ Siu M. Tsai, ${ }^{21}$ A. S. Zanca, ${ }^{19}$ Andrew J. G. Simpson, ${ }^{22}$ Stevens M. Brumbley, ${ }^{23}$ and João C. Setúbal ${ }^{24}$

${ }^{1}$ Escola Superior de Agricultura Luiz de Queiroz, Universidade de São Paulo, Av. Pádua Dias, 11, 13418-900, Piracicaba, SP, Brazil; ${ }^{2}$ Instituto de Biociências, Universidade de São Paulo, R. do Matão, 277, 05508-900, São Paulo, SP, Brazil; ${ }^{3}$ Alellyx Applied Genomics, R. James Clerk Maxwell 320, 13067-850, Campinas, SP, Brazil; ${ }^{4}$ Embrapa Recursos Genéticos e Biotecnologia, 70770-900 Brasília-DF, Brazil; ${ }^{5}$ Instituto Biológico Av. Conselheiro Rodrigues Alves, 1252, 04014-002, São Paulo, SP, Brazil; ${ }^{6}$ Faculdade de Ciências Agrárias e Veterinárias, Universidade Estadual Paulista, Av. Prof. Paulo D, Castellane s/n, 14884-900, Jaboticabal, SP, Brazil; " 7 Dept. of Microbiology, University of Washington, HSB, H310G, Bx 357242, Seattle, WA 98195-7242, U.S.A.; ${ }^{8}$ Centro de Citricultura Sylvio Moreira, 13490-000, Cordeirópolis, SP, Brazil; ${ }^{9}$ Instituto de Química, Universidade de São Paulo, Av. Prof. Lineu Prestes, 748, 05508-900, São Paulo, SP, Brazil; ${ }^{10}$ Faculdade de Ciências Agronômicas, Universidade Estadual Paulista, C. P. 237, 18603-970, Botucatu, SP, Brazil; ${ }^{11}$ Instituto Ludwig de Pesquisa sobre o Câncer, Rua Prof. Antonio Prudente, 109, 01509-010, São Paulo, SP, Brazil; ${ }^{12}$ Centro de Ciências Exatas e Tecnologia, Universidade Federal do Mato Grosso do Sul, C. P. 549, 79070-900, Campo Grande, MS, Brazil; ${ }^{13}$ Centro de Ciências Agrárias, Universidade Federal de São Carlos, C. P. 153, 13600-970, Araras, SP, Brazil; ${ }^{14}$ Faculdade de Filosofia, Ciências e Letras, Universidade de São Paulo, Av. Bandeirantes, 3900, 14040-901, Ribeirão Preto, SP, Brazil; ${ }^{15}$ Faculdade de Ciências Farmacêuticas de Ribeirão Preto, Universidade de São Paulo, Av. do Café S/N, 14040-903, Ribeirão Preto, SP, Brazil; ${ }^{16}$ Instituto de Ciências Biomédicas, Universidade de São Paulo, Av. Prof. Lineu Prestes, 1374, 05508-900, São Paulo, SP, Brazil; ${ }^{17}$ Instituto de Biociências, Universidade Estadual Paulista, 18618-000, Botucatu, SP, Brazil; ${ }^{18}$ Núcleo Integrado de Biotecnologia, Universidade de Mogi das Cruzes, Av. Dr. Cândido Xavier de Almeida Souza, 200, 08780-911, Mogi das Cruzes, SP, Brazil; ${ }^{19}$ Instituto de Biociências, Universidade Estadual de Campinas, C. P. 6109, 13083-970, Campinas, SP, Brazil; ${ }^{20}$ Instituto Agronômico de Campinas, C. P. 28, 13001-970, Campinas, SP, Brazil; ${ }^{21}$ Centro de Energia Nuclear na Agricultura, Universidade de São Paulo, C. P. 96, 13400-970, Piracicaba, SP, Brazil; ${ }^{22}$ Ludwig Institute for Cancer Research, 605 Third Avenue, New York, NY 10158, U.S.A.; ${ }^{23}$ BSES Limited, 50 Meiers Road, Indooroopilly, Queensland, 4068 and The CRC for Tropical Plant Protection, University of Queensland, St. Lucia, Queensland, 4072, Australia; ${ }^{24}$ Instituto de Computação, C.P. 6176, Universidade Estadual de Campinas, Campinas, SP, 13084-971 Brazil

Submitted 16 February 2004. Accepted 5 April 2004.

The genome sequence of Leifsonia xyli subsp. xyli, which causes ratoon stunting disease and affects sugarcane worldwide, was determined. The single circular chromosome of Leifsonia xyli subsp. xyli CTCB07 was $2.6 \mathrm{Mb}$ in length with a GC content of $68 \%$ and 2,044 predicted open reading frames. The analysis also revealed 307 pre-

Corresponding author: L. E. Camargo; Telephone: +55 19-34294124; Fax: +55 19-34344839; E-mail: leacamar@ carpa.ciagri.usp.br

Nucleotide sequence data for the L. xyli subsp. xyli CTCB07 chromosome reported in this paper are available in the GenBank database under accession number AE016822. Sequence data for CTCB07 has been deposited in the Biological Institute Culture Collection of Phytopathogenic Bacteria database under accession number IBSBF 1853.

*The Spotlight logo represents articles that, in the opinion of the senior editor and editor-in-chief, are of special interest to a broad readership.

** The $\boldsymbol{e}$-Xtra logo stands for "electronic extra" and indicates the HTML abstract available on-line contains five supplemental tables not included in the print edition. dicted pseudogenes, which is more than any bacterial plant pathogen sequenced to date. Many of these pseudogenes, if functional, would likely be involved in the degradation of plant heteropolysaccharides, uptake of free sugars, and synthesis of amino acids. Although $L$. xyli subsp. $x y l i$ has only been identified colonizing the xylem vessels of sugarcane, the numbers of predicted regulatory genes and sugar transporters are similar to those in freeliving organisms. Some of the predicted pathogenicity genes appear to have been acquired by lateral transfer and include genes for cellulase, pectinase, wilt-inducing protein, lysozyme, and desaturase. The presence of the latter may contribute to stunting, since it is likely involved in the synthesis of abscisic acid, a hormone that arrests growth. Our findings are consistent with the nutritionally fastidious behavior exhibited by $L$. xyli subsp. $x y l i$ and suggest an ongoing adaptation to the restricted ecological niche it inhabits. 
Leifsonia xyli subsp. xyli is a member of the gram-positive GC-rich order Actinomycetales, which includes important members with fully sequenced genomes, such as the human pathogens Mycobacterium tuberculosis (Cole et al. 2000), Mycobacterium leprae (Cole et al. 2001), and Tropheryma whipplei (Bentley et al. 2003; Raoult et al. 2003), the industrial species Streptomyces coelicolor (Bentley et al. 2002) and Streptomyces avermitilis (Omura et al. 2001), as well as a commensal of the human gastrointestinal tract Bifidobacterium longum (Schell et al. 2002).

The genus Leifsonia comprises seven species that have been isolated from distinct niches, such as plants, soil, distilled water, and an Antarctic pond (Janssen et al. 2002; Leifson 1962; Suzuki et al. 1999; Reddy et al. 2003). Leifsonia xyli comprises two subspecies: L. xyli subsp. cynodontis, a pathogen that causes stunting in Bermuda grass (Cynodon dactylon) and $L$. xyli subsp. xyli (Evtushenko et al. 2000). Information on the biology and pathogenicity of L. xyli subsp. xyli is limited, not only because it has recently been recognized as the causal agent of the ratoon stunting disease (Davis et al. 1980) but also because it grows poorly in vitro. So far, L. xyli subsp. xyli has only been identified in association with sugarcane and does not appear to be a soil-borne pathogen (Gillaspie and Teakle 1989). Moreover, despite extensive surveys, L. xyli subsp. xyli has never been found affecting wild sugarcane in its center of diversity (Magarey et al. 2002), Papua New Guinea, which suggests a recent contact with its host. Because sugarcane is a perennial grass and crops are normally harvested up to seven times, the predominant mode of transmission of the pathogen in commercial fields is mechanical, via contact with the sap of infected plants during harvesting with machines and knives. Natural mechanisms of infection are unknown, although no systematic search for insect vectors or alternative hosts has been undertaken. L. xyli subsp. xyli colonizes the lumen and the pits of the xylem vessels but not the phloem or parenchyma (Weaver et al. 1977). No general tissue disorganization results from this colonization, although the xylem may be blocked with a mucilaginous substance probably produced by the host. This blockage is reported to reduce sap flow up to $34 \%$ (Teakle et al. 1978). Infection with $L$. xyli subsp. xyli results in reduced cane diameter and plant stunting, symptoms that are often misinterpreted as general growth defects due to poor crop management. Ratoon stunting disease is regarded as the main disease of sugarcane worldwide. Yield losses of both cane and sugar per unit area may approach $50 \%$ in highly susceptible genotypes (Gillaspie and Teakle 1989). Annual losses were estimated at US\$11 million in Australia (Fegan at al. 1998) and US\$36 million in

Table 1. Chromosomal features of Leifsonia xyli subsp. xyli CTCB07

\begin{tabular}{ll}
\hline Feature & Property \\
\hline Length & $2,584,158 \mathrm{bp}$ \\
Coding region & \\
GC content & $70.6 \%$ \\
Total number of genes (intact protein-coding genes & $67.7 \%$ \\
$\quad$ and pseudogenes) & 2,351 \\
Intact protein-coding genes & 2,044 \\
Intact protein-coding genes with functional assignment & $1,370(58 \%)$ \\
Conserved hypothetical open reading frames (ORF) & $353(15 \%)$ \\
$\quad$ intact) & $321(14 \%)$ \\
Hypothetical ORF (intact) & $307(13 \%)$ \\
ORF representing pseudogenes (including transposase- & \\
$\quad$ enconding genes) & 45 \\
tRNA & 1 \\
Ribosomal RNA operons & 50 \\
Insertion sequence &
\end{tabular}

${ }^{a}$ The coding region was calculated by adding up the sizes of intact open reading frames and RNA-coding genes and dividing the sum by the genome length.
Florida (Dean and Davis 1989). In Brazil, despite being regarded as the most important disease of sugarcane, precise estimates of yield losses due to the disease are unavailable. L. $x y l i$ subsp. xyli can be grown in vitro but its growth is slow and dependent on supplementation with cysteine, as described previously (Davis et al. 1984). Along with Xylella fastidiosa, a gramnegative gamma-Proteobacterium that infects citrus and grapevine among other hosts, L. xyli subsp. xyli belongs to a unique group of xylem-limited and fastidious bacterial plant pathogens (Purcell and Hopkins 1996). In this study, we report the genome sequence of a pathogenic strain of $L$. xyli subsp. xyli and discuss the possible consequences of gene loss and gene acquisition on the ecology and pathogenicity of this organism.

\section{RESULTS AND DISCUSSION}

\section{Genome features.}

The genome of Leifsonia xyli subsp. xyli CTCB07 (CTCB07) comprises a single circular chromosome of 2,584,158 base pairs (Fig. 1 and Table 1). Only 70.6\% of the nucleotide sequence of the genome of CTCB07 contains intact open reading frames (ORF), the remaining being represented by pseudogenes or noncoding DNA sequence. This percentage is below the lowest value of $80 \%$ observed for most bacterial genomes (Moran 2002). Approximately 13\% of the putative protein-coding genes (307), which accounts for $11.6 \%$ of the nucleotide sequence of the genome, are predicted to be pseudogenes, i.e., gene fragments arising from authentic frameshifts or deletions due to point mutations that introduced or removed a stop codon in frame or, alternatively, genes that are incomplete. From these, 51 are transposase-encoding genes and the remaining were assigned to different functional categories. Interspersed noncoding DNA corresponds to $17.7 \%$ of the nucleotide sequence. In many cases these intercoding spaces revealed similarity to portions of genes, indicating that they could represent gene remnants.

Five distinct insertion sequence (IS) families were identified, accounting for 50 insertions distributed throughout the chromosome. These elements, named ISLxx1 through ISLxx5, are related to major IS families such as IS110 (ISLxx2), IS21 (ISLxx1 and ISLxx3), IS481 (ISLxx4), and IS30 (ISLxx5) that are defined by their conserved amino acid motif (DDE) in the transposase. Of these, ISLxx 4 and ISLxx 5 are the most represented and are present, respectively, in 26 and 15 nearly identical copies. Ten ISLxx 4 and five ISLxx 5 copies are inserted in the close vicinity of or within genes with known functions such as ABC transporters, potassium channel, and regulatory elements. This suggests that members of the IS481 and IS30 families were recently capable of proliferating and, if still active, have the potential to mutagenize the genome of $L$. xyli subsp. xyli.

An additional 37 transposases that could not be classified into one of the five ISLxx elements were identified that are primarily associated with the genomic islands described below. Together, IS elements and transposases comprise a large proportion of the genome $(3.5 \%)$, a percentage similar to that observed in Yersinia pestis (Parkhill et al. 2001).

\section{General metabolism.}

Our analyses suggest that CTCB07 has the potential to encode complete glycolytic, penthose phosphate, and tricarboxylic acid cycle pathways. However, CTCB07 does not contain any of the 14 known proteins of the oxidative phosphorylation complex I. This system is also missing in Mycobacterium leprae, Bacillus subtilis, Haemophilus influenzae, and Vibrio cholerae. Each of these organisms may transfer hydrogen from $\mathrm{NADH}$ to ubiquinone using a type II NADH dehydrogenase 
(EC 1.6.99.3) or a $\mathrm{Na}+$ transporting NADH:ubiquinone oxidoreductase. CTCB07 presents a homolog of the former that is highly similar to the one present in Streptomyces coelicolor. The generation of ATP by CTCB07 is achieved by an F-type ATP synthase. All genes coding for enzymes of the gluconeogenesis pathway are present except fructose 1,6-biphosphatase, which is also absent in other Actinobacteria. The de novo fatty acid biosynthetic pathway of CTCB07 is remarkably similar to that of Tropheryma whipplei. Likewise, the multifunctional fatty acid synthase I polypeptide and cma genes, responsible for the production of mycolic acids, are not present. The presence of two copies of 3-phosphatidyltransferases might explain the predominance of phosphatidylglycerol and diphosphatidylglycerol among the phospholipids. CTCB07 appears
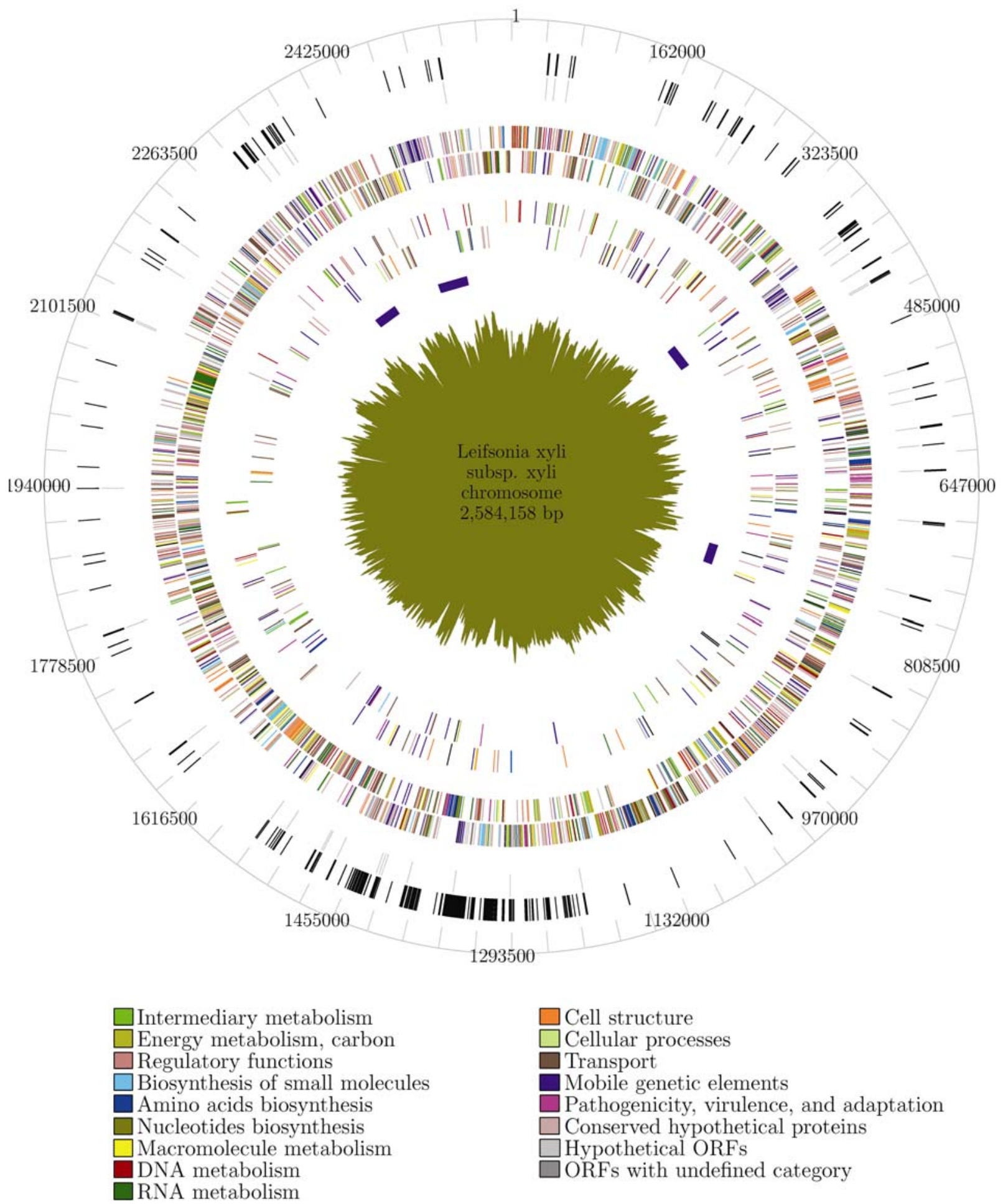

Cell structure

Cellular processes

Transport

Mobile genetic elements

Pathogenicity, virulence, and adaptation

Conserved hypothetical proteins

Hypothetical ORFs

ORFs with undefined category

Fig. 1. The circular genome of Leifsonia xyli subsp. xyli CTCB07. The outer scale corresponds to coordinates in base pairs. The first (outer) circle indicates Tnp insertions as previously reported (Brumbley et al. 2004). The second indicates the positions of insertion sequences. The third and fourth circles represent predicted coding regions color-coded by gene category of the plus and minus strands, respectively. Genes on the fifth and sixth circles are pseudogenes (plus and minus strands); seventh circle, genomic islands as defined by three criteria: codon bias, GC composition, and dinucleotide signatures; and eighth circle (innermost), $\mathrm{G}+\mathrm{C}$ content. 
to encode enzymes necessary for the synthesis of folic acid, pantothenate, pyridoxine, riboflavin, and nicotinate but lacks those involved in the synthesis of cobalamin. CTCB07 may require external biotin and thiamine, since most of the enzymes involved in the synthesis of these vitamins, which are common among other bacteria, are missing in CTCB07.

\section{Ecology of CTCB07.}

Both L. xyli subsp. xyli and X. fastidiosa inhabit the plant xylem and have similarly sized genomes. However, unlike $X$. fastidiosa, and quite unexpectedly for an organism that survives on the carbon-poor sap of sugarcane (Dong et al. 1997), CTCB07 has a number of genes involved in sugar intake and gene regulation. Surprisingly, the number of these genes is comparable to the levels found in free-living soil organisms (Fig. 2). This suggests that CTCB07 might spend part of its life cycle outside of its host. For instance, CTCB07 has a larger number of $\mathrm{ABC}$ transporters as compared with $X$. fastidiosa (30 as opposed to 5) and is capable of utilizing a range of carbohydrates including arabinose, fructose, galactose, glycerol, glucose, lactose, maltose, maltotriose, ribose, trehalose, and xylose. In addition, CTCB07 has a complete phosphoenolpyruvate-dependent phosphotransferase system (PTS) for the transport of fructose and mannitol. PTS systems are ab-

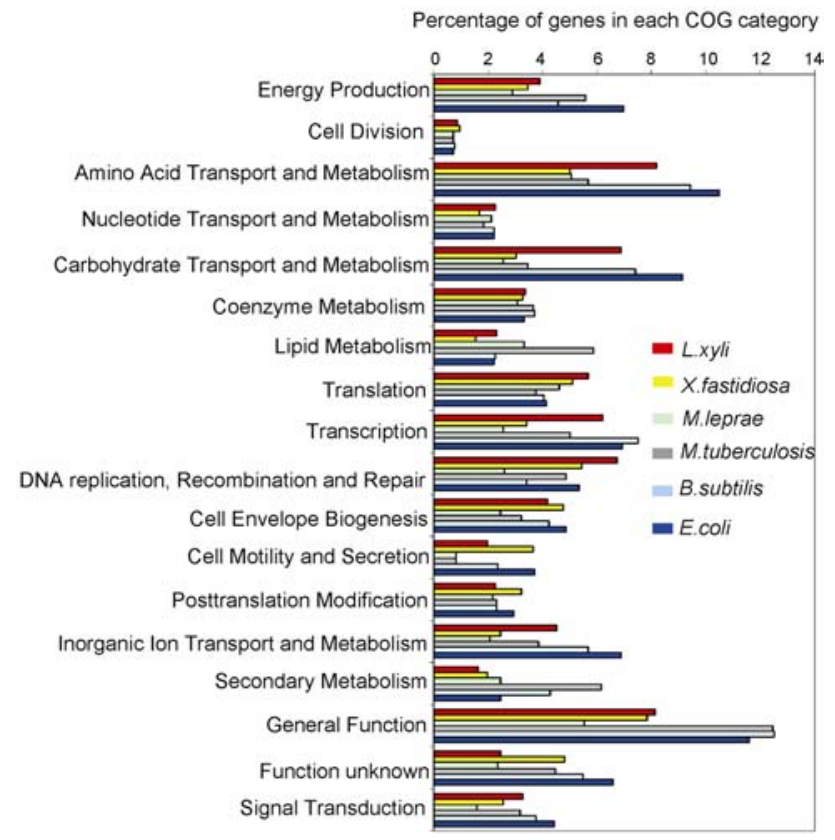

Fig. 2. Percentage of the total number of genes in each functional category as defined by COG (clusters of orthologous groups). sent in $X$. fastidiosa. Moreover, $6.6 \%$ of all ORF are predicted to be involved in gene regulation based on the occurrence of regulatory motifs. This number is higher than that seen in $X$. fastidiosa (4.4\%) and closer to that found in the similar-sized genome of the free-living organism Caulobacter crescentus (7.7\%). Finally, the presence of a photolyase, a flagellar operon (discussed below), genes involved in protection against hyper- or hypo-osmotic conditions such as trehalose synthase and phosphatase, mechanosensitive channels, carotenoid biosynthesis, and two operons encoding ABC-type glycine and betaine transporters (one of which has likely been rendered inoperative as a consequence of the insertion of ISLxx4) further strengthen the hypothesis that CTCB07 has, or at least at one time had, the capacity to live as a free-living organism. This is paradoxical, as there are no records indicating that $L$. xyli subsp. xyli is able to survive in the soil after removal of the host (Gillaspie and Teakle 1989). However, it is possible that $L$. xyli subsp. xyli inhabits as yet unidentified niches. An alternative explanation is that $L$. $x y l i$ subsp. $x y l i$ once inhabited diverse niches but is now restricted to the sugarcane environment due to the loss of key genes as described below.

\section{Pseudogenes.}

Although pseudogenes are not as numerous as in the related species Mycobacterium leprae (Cole et al. 2000), they occur much more frequently in CTCB07 than in any other completely sequenced genome of plant-associated bacterium (Table 2). These pseudogenes, if intact, would have allowed CTCB07 to live on plant debris including those involved in the degradation of plant heteropolysaccharides ( $\beta$-galactosidase and $\alpha$ - and $\beta$ mannosidases) and cellobiose ( $\beta$-glucosidase), a major disaccharide product of cellulose degradation. None of these genes have identifiable functional homologs elsewhere in the genome. The metabolism of galactose and glutarate are also compromised due to the inactivation of galactokinase and glutarylCoA dehydrogenase, respectively. Finally, a relatively large number of ABC transporters (14 out of 30 ) are predicted to be pseudogenes.

In addition to its role in restricting the ecological range of CTCB07, the loss of genes involved in basic metabolism and synthesis of amino acids may also contribute to its fastidious behavior. Noteworthy among these are genes involved in the synthesis of cysteine and methionine. The sulfite and sulfate cysteine biosynthetic pathway is affected by the loss of cysteine synthase. Although CTCB07 may synthesize this amino acid via a cystathionine pathway in a manner similar to that of Bifidobacterium longum (Schell et al. 2002), the fact that the in vitro growth of CTCB07 is cysteine-dependent (Davis et al. 1980) may result from the loss of cysK. Two genes involved in the biosynthesis of methionine, met $\mathrm{E}$ and $m e t \mathrm{~F}$, both part of the folate branch of the pathway, are also pseudogenes. More-

Table 2. Pseudogene counts in various organisms

\begin{tabular}{lcc}
\hline Organism & Protein-coding genes & Pseudogenes (\% of total number of genes) \\
\hline Leifsonia xyli subsp. xyli CTC B07 & 2,326 & $307(13.0 \%)$ \\
Xylella fastidiosa 9a5c & 2,249 & $66^{\mathrm{a}}(2.9 \%)$ \\
Xanthomonas axonopodis pv. citri & 4,427 & $85^{\mathrm{a}}(1.9 \%)$ \\
Xanthomonas campestris pv. campestris & 4,181 & $73^{\mathrm{a}}(1.7 \%)$ \\
Agrobacterium tumefaciens C58 & 5,415 & $13^{\mathrm{a}}(0.2 \%)$ \\
Ralstonia solanacearum & 5,036 & $38^{\mathrm{b}}(0.8 \%)$ \\
Mycobacterium leprae TN & 2,653 & $905^{\mathrm{b}}(34.1 \%)$ \\
Rickettsia prowasekii Madrid E & 797 & $40^{\mathrm{b}}(5.0 \%)$ \\
Sinorhizobium meliloti & 6,138 & $57^{\mathrm{b}}(0.9 \%)$ \\
Streptomyces coelicolor & 8,093 & $447^{\mathrm{b}}(5.5 \%)$ \\
Pseudomonas syringae & 5,400 & $60^{\mathrm{b}}(1.2 \%)$ \\
\hline
\end{tabular}

a Source: GenBank.

${ }^{\mathrm{b}}$ Source: Pseudogenes and Intergenic Analyses website. 
over, the gene that codes for MetH, which accomplishes the same role as MetE in converting homocysteine into methionine, is absent. Although there are no reports indicating that $L$. $x y l i$ subsp. xyli is a methionine auxotroph, we experimentally determined that the growth of CTCB07 in culture is greatly improved if this amino acid is added to the standard growth medium (Fig. 3), thus suggesting that the loss of met $\mathrm{E}$ and met $\mathrm{F}$ partly explains the fastidious behavior of this bacterium.

\section{Pathogenicity genes.}

The paucity of known genes putatively involved in pathogenicity identified in the genome of CTCB07 possibly accounts for the stealthy infection it causes in sugarcane. Only 105 genes were assigned to the pathogenicity category, of which $20(18 \%)$ are predicted pseudogenes. This is the smallest number of genes in this category reported so far for a plant pathogenic bacterium (Table 3). It is approximately 20 and $62 \%$ less than that reported in the genomes of two $X$. fastidiosa strains (Simpson et al. 2000; Van Sluys et al. 2003) and two Xanthomonas species (da Silva et al. 2002), respectively.

\section{Hemolysins, hemagglutinins, and adhesins.}

CTCB07 carries genes that are predicted to encode proteins similar to bacterial hemolysins, hemagglutinins, and adhesinrelated proteins. These include proteins similar to the TlyA and TlyC hemolysins of the spirochete Serpulina. In addition, CTCB07 has a gene that codes for a predicted surface protein similar to TadA of Actinobacillus actinomycetemcomitans, a type IV secretion ATPase involved in the production of an adhesin. Moreover, as in Tropheryma whipplei, the gene that codes for TadA is the first of a sequence of five membrane-associated proteins whose presence suggests the existence of a surface apparatus involved in adherence to host cells. In CTCB07, however, the gene coding for this protein is interrupted by the insertion of a genomic island named LxxGI1 (discussed below). The presence of genes coding for proteins that are involved in interactions with live host cells seems contradictory in a pathogen that inhabits a plant tissue (xylem) mostly composed of cells that lack protoplast at maturity. However, some xylem elements with intact cytoplasm can be found in sugarcane just below the cane node (Dong et al. 1997), indicating that this would be a potential locality for intimate contact with live host cells. Interestingly, a conspicuous discoloration of the vascular bundles can be seen right below the nodes of susceptible cane varieties infected with CTCB07 and might be one of the outcomes of such contact.

\section{Quorum-sensing and motility.}

Genes involved in quorum-sensing were identified, including proteins similar to zinc metalloprotease, involved in the synthesis of pheromones in Enterococcus faecalis (An et al.
1999), and the butyrolactone receptor SpbR of Streptomyces pristinaespiralis, which is a member of the TetR regulator (repressor) family (Folcher et al. 2001). The existence of another signaling mechanism is suggested by the presence of a cluster of genes predicted to encode membrane proteins including one with a sortase domain and another with a membrane protein rhomboid (RHO) domain. Both sortase and RHO domains are known to have proteolytic activities and the latter has been implicated in the release of quorum-sensing signals (Gallio et al. 2002). Conserved hypothetical proteins carrying a rhomboid-like domain are among the few that are shared among the plant-associated bacteria sequenced to date (Van Sluys et al. 2002).

A flagellar operon comprised of $28 \mathrm{ORF}$ is also present in CTCB07. However, predicted proteins required for assembly of the flagellar filament (FlgK, FliD, and FliK) and for the export of flagellin (FlhA) are encoded by pseudogenes, suggesting that full assembly of the flagellum is not possible. Consistent with these findings, electron microscopy indicates that $L$. xyli subsp. xyli lacks flagella (Kao and Damann 1978; Weaver et al. 1977). Given the established roles of flagellar proteins in hostparasite interactions, including adhesion and transfer of virulence proteins to animal host cells (Arora et al. 1998; Ghelardi et al. 2002), virulence in plant hosts (Chesnokova et al. 1997; Ichinose et al. 2003; Matsumoto et al. 2003; Tans-Kersten et al. 2001), and induction of rapid cell death in nonhost plants (Tagushi et al. 2003), it would be interesting to determine whether intact operons occur in other strains of $L$. xyli subsp. $x y l i$ and to establish the role of such an intact cellular apparatus, if any, on the virulence of L. xyli subsp. xyli.

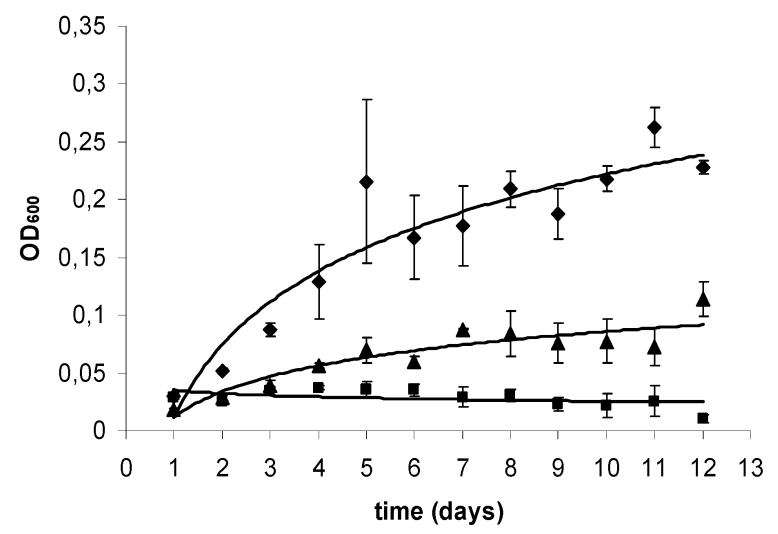

Fig. 3. Growth of Leifsonia xyli subsp. xyli cells in MSCnew liquid media in the presence and absence of methionine $(5 \mathrm{mg} / \mathrm{ml})$. Growth was evaluated by measuring the optical density at $600 \mathrm{~nm}$ of the liquid media. $\mathbf{\square}=$ MSCnew without cysteine; $\boldsymbol{\Delta}=$ MSCnew + cysteine; and $\boldsymbol{\nabla}=$ MSCnew + cysteine + methionine.

Table 3. Number of putative genes involved in virulence and pathogenicity of the different plant pathogens ${ }^{\mathrm{a}}$

\begin{tabular}{|c|c|c|c|c|c|c|c|c|}
\hline Category & $R s^{b}$ & $X a c$ & $X c c$ & Psy & Atu & $X f-C V C$ & $X f-P D$ & $L x x^{c}$ \\
\hline Type III secretion system-related functions & 34 & 35 & 35 & 87 & 0 & 0 & 0 & 0 \\
\hline Toxin production and detoxification & 133 & 134 & 111 & 30 & 93 & 69 & 63 & $27(6)$ \\
\hline Host cell wall degradation & 13 & 20 & 24 & 6 & 4 & 6 & 6 & $6(2)$ \\
\hline Exopolysaccharides & 0 & 15 & 14 & 3 & 3 & 9 & 13 & 3 \\
\hline Surface proteins & 35 & 14 & 11 & 71 & 28 & 6 & 15 & $31(10)$ \\
\hline Adaptation, atypical conditions & 22 & 25 & 26 & 70 & 21 & 16 & 28 & $36(1)$ \\
\hline Other & 33 & 59 & 66 & 31 & 57 & 28 & 34 & $2(1)$ \\
\hline Total number of genes & 270 & 302 & 287 & 298 & 206 & 134 & 159 & $105(20)$ \\
\hline
\end{tabular}

${ }^{\text {a }}$ Homologs were identified using BLASTP $\left(E<10^{-5}\right)$, as described previously (Van Sluys et al. 2002). The only exception is Pseudomonas syringae pv. tomato, for which the data was collected from the Pseudomonas syringae genome project (Buell et al. 2003).

${ }^{\mathrm{b}} R s=$ Ralstonia solanacearum, Xac = Xanthomonas axonopodis pv. citri, Xcc = Xanthomonas campestris pv. campestris, Psy = Pseudomonas syringae pv. tomato, Atu = Agrobacterium tumefaciens, Xf-CVC =Xylella fastidiosa 9a5C, Xf-PD =Xylella fastidiosa Temecula 1, and Lxx $=$ Leifsonia xyli subsp. xyli.

${ }^{c}$ The number of Leifsonia xyli subsp. xyli pseudogenes in each category is indicated in parenthesis. 


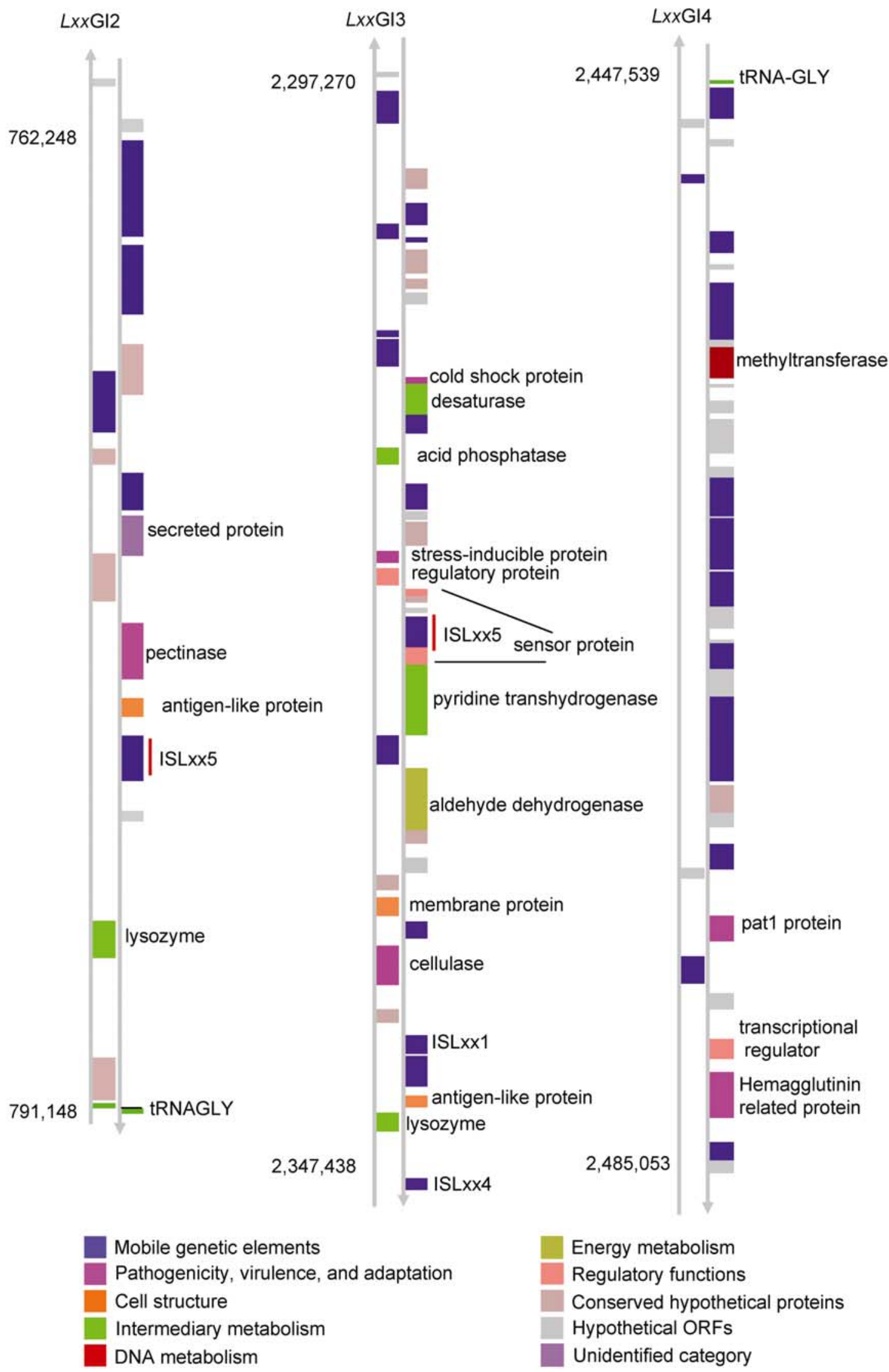

Fig. 4. Description of Leifsonia xyli subsp. xyli genomic islands 2 throug 4 of CTCB07. All genes (minus and plus strains represented by gray-arrowed lines) are color-coded by category. 


\section{Secretion systems.}

Protein secretion in gram-positive bacteria is facilitated due to the low structural complexity of the cell wall compared with gram-negative bacteria (Madden et al. 2001). As a consequence, none of the five typical secretion systems (I through V) described for gram-negative bacteria are present in CTCB07. Also absent is the cytolisin-mediated translocation (CMT) system described in Streptococcus pyogenes (Madden et al. 2001). CMT has been implicated in the secretion of streptolysin $\mathrm{O}$ into host cells and, thus, is regarded as a functional gram-positive equivalent of the Type III secretion system of gram-negative bacterial pathogens. However, other secretion systems commonly found in gram-positive bacteria were found. Several genes encoding proteins of a general secretion pathway have been identified: sec A (translocation motor), sec $\mathrm{D} / \mathrm{F}, \sec \mathrm{Y}, \sec \mathrm{E}$, sec $\mathrm{G}$, and yaj $\mathrm{C}$ (translocation channel). As with Bacillus subtilis, CTCB07 has no gene encoding the $\mathrm{SecB}$ chaperone, but other chaperones and targeting factors, such as Ffh and FtsY, may substitute for the SecB function. General chaperones such as GroES and GroEL are present. Three genes encoding a type I signal peptidase were found in CTCB07 but, unlike E. coli, Bacillus subtilis, or Brucella melitensis, CTCB07 has neither genes encoding a type II signal peptidase required for processing of lipo-modified precursors nor those encoding soluble inorganic pyrophosphatases (sppA and tepA), which are responsible for degradation of the signal peptide. CTCB07 is predicted to encode a protein similar to FkpA of E. coli that is involved in the refolding of mature proteins after their translocation through the membrane. The twin arginine motif translocation (TAT) pathway accomplishes the secretion of folded cofactor-containing proteins across the membrane. Of the five known Tat proteins (A through E), TatE (TatA paralogue), TatC, and TatD are present in CTCB07.

\section{Lateral gene transfer and virulence.}

The genome of CTCB07 harbors several regions with altered GC content compared with the rest of the genome (Fig. 1, innermost circle). Four such regions (coded LxxGI1 to LxxGI4) with GC composition around 63\% also presented altered codon bias and dinucleotide signatures and thus were designated as putative genomic islands (Karlin et al. 1998). LxxGI1 is $33 \mathrm{kbp}$ long and resembles a degenerated prophage. It is inserted within a type IV secretion ATPase and is flanked by 15-bp direct repeats. Most of the genes within this region encode proteins similar to those found in bacteriophages or that have no similarity to other proteins in the databases. A striking feature of the other three regions (LxxGI2 to LxxGI4) is that they harbor candidate pathogenicity genes (Fig. 4). The 28-kbp LxxGI2 may be the result of a plasmid integration event, since it harbors genes involved in conjugation, including a gene coding for a relaxase/mobilization protein ( $\mathrm{Rlx})$ required for the horizontal transfer of plasmids. It also contains a pectinase-coding gene flanked by transposable elements whose predicted amino acid sequence is most similar to the endopolygalacturonases of the proteobacteria Xanthomonas axonopodis pv. citri and $X$. campestris pv. campestris, pathogens of citrus and Brassica species, respectively. Polygalacturonases are important virulence factors in plant pathogens as they degrade pectin in the plant cell walls, resulting in the maceration of host tissues (Collmer and Keen 1986). LxxGI3 is $50 \mathrm{kbp}$ in size and carries several transposases. In addition, it contains a gene coding for a cellulase similar to CelA of Clavibacter michiganensis subsp. michiganensis and C. michiganensis subsp. sepedonicus. In both species, celA is located on a plasmid and plays a decisive role in virulence. In C. michiganensis subsp. michiganensis, the gene confers a wilt-inducing phenotype when transferred to plasmid-free nonvirulent strains (Jahr et al. 2000), while in C. michiganensis subsp. sepedoni$c u s$, it is associated with increased virulence of low-virulent plasmid-free strains (Laine et al. 2000). Interestingly, LxxGI3 harbors a gene that codes for a member of the delta fatty acid desaturase family. The presence of this protein deserves special attention, since it could divert the carotenoid biosynthetic pathway identified in CTCB07 that enables the production of $\beta$-carotene from geranyl pyrophosphate and isopentenyl pyrophosphate (Armstrong 1997) to the synthesis of the plant hormone abscisic acid (ABA) (Bartley and Scolnik 1995; Kende and Zeevaart 1997). In plants, ABA is widely reported as a growth inhibitor. Thus, the production and secretion of this plant hormone could contribute to the symptoms of stunting seen in L. xyli subsp. xyli-infected plants. Plant pathogens are known to interfere with host growth by producing or inhibiting the production of host hormonal growth regulators (gibberellins, cytokinins, ethylene, and auxins). However, this is the first evidence that a bacterial plant pathogen may produce ABA.

The last genomic island, LxxGI4, also resembles a prophage and contains several genes of likely bacteriophage origin as well as hypothetical genes. This $37-\mathrm{kbp}$ region is integrated into a tRNAgly and bounded by two identical 30-bp sequences and one integrase. Most important, LxxGI4 harbors a gene similar to pat-1 of $C$. michiganensis subsp. michiganensis. In this organism, this plasmid-encoded gene plays a decisive role in causing plant wilting (Dreier 1997). Strains lacking this gene are only mildly virulent and do not cause wilting; however, transformation of these strains with pat-1 confers upon them the wilt-inducing phenotype. This phenotype is attenuated if a repetitive sequence positioned downstream of the gene (pat-1rep) is deleted. In CTCB07, the pat-1 homolog is present in two copies, although only the one present in LxxGI4 seems functional. This copy has the consensus motif of the trypsin family of serine proteases characteristic of pat-1, but lacks the downstream repetitive sequence. The absence of pat-1rep in CTCB07 may explain why this pathogen causes wilting only in highly susceptible sugarcane varieties under drought stress conditions.

Given the importance of the genes discussed above, they are suitable candidates for further functional studies geared toward determining the virulence mechanisms of CTCB07. For instance, pectinase and cellulase genes are present in the genomes of a number of bacterial plant pathogens (Arora et al. 1998). We predict that, in CTCB07, they play a primary colonization and adaptation role similar to that predicted for $X$. fastidiosa, since they would both enable these pathogens to migrate through the xylem vessels and to use pectin and cellulose as carbon sources (Van Sluys et al. 2002). Finally, since the genus Clavibacter is closely related to L. xyli subsp. xyli and was originally classified as Clavibacter xyli (Davis et al. 1984; Evtushenko et al. 2000), we speculate that the genomic islands containing celA and pat-1 and the Clavibacter plasmids have a common origin. This hypothesis may find additional support when the complete sequence of the plasmids of $C$. michiganensis subsp. sepedonicus and C. michiganensis subsp. michiganensis become available.

\section{Adaptation to the host.}

Microarray profiling and subsequent analyses of plantinduced bacterial genes have indicated that genes involved in adaptation to the host environment are more important than previously thought (Okinaka et al. 2002). Like other plant pathogens, CTCB07 has the potential to encode products that would enable it to cope with reactive oxygen species produced by the host as part of its general defense mechanism (superox- 
ide dismutase, catalase, iron dependent peroxidase, and alkyl hydroperoxide reductase). Also of interest is arginase, which catalyzes the conversion of arginine to urea and ornithine. In Helicobacter pylori, arginase inhibits the production of the antimicrobial nitric oxide (NO), thus representing an important mechanism of bacterial survival (Gobert et al. 2001). In the order Actinomycetales, this could be of special significance, since these organisms are unable to synthesize the antioxidant glutathione, which is regarded as a protectant against NO (Fang 1997).

The ability to cope with toxins produced by organisms that share the same niche is also of great adaptive value. In this respect, CTCB07 appears to encode a multidrug efflux pump similar to the AlbF system of Xanthomonas albilineans, a sugarcane pathogen that also resides within the vascular system of sugarcane (Rott et al. 1994). The production of the potent bacterial and plant toxin albicidin by $X$. albilineans is responsible for the main symptom it causes, i.e., scalding of the leaves as a result of blockage of chloroplast differentiation (Birch and Patil 1985, 1987). The AlbF system exports albicidin, thus protecting $X$. albilineans from its deleterious effects. Thus the presence of $a l b F$ in $\mathrm{CTCB} 07$ may render it resistant to this toxin, enabling it to colonize the plant host in the presence of $X$. abilineans. Casual observations of simultaneous infections of $L$. xyli subsp. xyli and $X$. albilineans in the field support this conclusion.

\section{Concluding remarks.}

The analysis of the genome sequence of CTCB07 provided insights into important biological aspects of L. xyli subsp. xyli. The large number of pseudogenes found in CTCB07 in the context of plant pathogenic bacteria suggests an ongoing process of genome decay similar to that described in Mycobacterium leprae (Cole et al. 2001), Coxiella burnetti (Seshadri et al. 2003), and Rickettsia spp. (Andersson et al. 1998). The loss of functions associated to these pseudogenes may be redirecting the lifestyle of $L$. xyli subsp. xyli from a free-living to a fastidious xylem-limited organism. The limited number of pathogenicity genes appears to explain why L. xyli subsp. xyli may be regarded as the near-perfect pathogen (Metzler et al. 1997), since it is able to reach high bacterial titers in the host without causing significant symptoms. It is intriguing to speculate whether the genes putatively acquired by lateral transfer here described could have turned this bacterium from a freeliving plant commensal into a pathogen. Consistent with this idea, bacteria similar to Leifsonia xyli have been reported as endophytes of various grass species (Mills et al. 2001). Given this, comparative genomic studies of CTCB07 and other Leifsonia spp. will be of great value in our efforts to understand the evolution of pathogenesis.

\section{MATERIALS AND METHODS}

\section{Sequencing and annotation.}

The genome of strain CTCB07 was determined by a combined shotgun and cosmid insert sequencing approach as previously described (da Silva et al. 2002). The Agronomical and Environmental Genomes Consortium carried out library construction, sequencing, assembly, finishing, and annotation. Bioinformatics analyses (genome annotation tools, comparative genomics, COG, and PFAM) were performed as previously described (Van Sluys et al. 2003; Wood et al. 2001). All intergenic regions were checked for the presence of possible undetected ORF by performing blastX searches against the GenBank database.

CTCB07 was chosen for sequencing based on its routine use in the selection of ratoon stunting resistant sugarcane varieties in the breeding program of COPERSUCAR, a Brazilian cooperative of sugarcane growers.

\section{ACKNOWLEDGMENTS}

This project was funded by FAPESP (São Paulo, Brazil), COPERSUCAR (São Paulo, Brazil), and CNPq (Brasília, Brazil). We thank all of the technicians involved in this project.

\section{LITERATURE CITATIONS}

An, F. Y., Sulavik, M. C., and Clewell, D. B. 1999. Identification and characterization of a determinant (Eep) on Enterococcus faecalis chromosome that is involved in production of the peptide sex cAD1. J. Bacteriol. 181:5915-5921

Andersson, S. G. E., Zomorodipour, A., Andersson, J. O., SicheritzPontén, T., Alsmark, U. C. M., Podowski, R. M., Näslund, A. K., Eriksson, A.-S., Winkeler, H. H., and Kurland, C. G. 1998. The genome sequence of Rickettsia prowazekii and the origin of mitochondria. Mol. Biol. Evol. 16:1178-1191.

Armstrong, G. A. 1997. Genetics of eubacterial carotenoid biosynthesis: A colorful tale. Annu. Rev. Microbiol. 51:629-659.

Arora, S. K., Ritchings, B. W., Almira, E. C., Lory, S., and Ramphal, R. 1998. The Pseudomonas aeruginosa flagellar cap protein, FliD, is responsible for mucin adhesion. Infect. Immun. 66:1000-1007.

Bartley, G. E., and Scolnik, P. A. 1995. Plant carotenoids: Pigments for photoprotection, visual attraction, and human health. Plant Cell 7:10271038.

Bentley, S. D., Chater, K. F., Cerdeño-Tárraga, A.-M., Challis, G. L. Thomson, N. R., James, K. D., Harris, D. E., Quail, M. A., Kieser, H., Harper, D., Bateman, A., Brown, S., Chandra, G., Chen, C. W., Collins, M., Cronin, A., Fraser, A., Goble, A., Hidalgo, J., Hornsby, T., Howarth, S., Huang, C.-H., Kieser, T., Larke, L., Murphy, L., Oliver, K., O’Neil, S., Rabbinowitsch, E., Rajandream, M.-A., Rutherford, K., Rutter, S. Seeger, K., Saunders, D., Sharp, S., Squares, R., Squares, S., Taylor, K., Warren, T., Wietzorrek, A., Woodward, J., Barrell, B. G., Parkhill, J., and Hopwood, D. A. 2002. Complete genome sequence of the model actinomycete Streptomyces coelicolor A3(2). Nature 417:141-147.

Bentley, S. D., Maiwald, M., Murphy, L. D., Pallen, M. J., Yeats, C. A. Dover, L. G., Norbertczak, H. T., Besra, G. S., Quail, M. A., Harris, D. E., von Herbay, A., Goble, A., Rutter, S., Squares, R., Squares, S., Barrell, B. G., Parkhill, J., and Relman, D. A. 2003. Sequencing and analysis of the genome of the Whipple's disease bacterium Tropheryma whipplei. Lancet 361:637-644.

Birch, R. G., and Patil, S. S. 1985. Preliminary characterization of an antibiotic produced by Xanthomonas albilineans which inhibits DNA synthesis in Escherichia coli. Gen. Microbiol. 131:1069-1075.

Birch, R. G., and Patil, S. S. 1987. Evidence that an albicidin-like phytotoxin induces chlorosis in sugarcane leaf scald disease by blocking plastid DNA-replication. Physiol. Mol. Plant Pathol. 30:207-214.

Brumbley, S. M., Petrasovits, L. A., Murphy, R. M., Nagel, R. J., Candy, J. M., and Hermann, S. R. 2004. Establishment of a functional genomics platform for Leifsonia xyli subsp. xyli. Mol. Plant-Microbe Interact. 17:175-183.

Buell, C. R., Joardar, V., Lindeberg, M., Selengut, J., Paulsen, I. T., Gwinn, M. L., Dodson, R. J., Deboy, R. T., Durkin, A. S., Kolonay, J. F., Madupu, R., Daugherty, S., Brinkac, L., Beanan, M. J., Haft, D. H., Nelson, W. C., Davidsen, T., Zafar, N., Zhou, L., Liu, J., Yuan, Q., Khouri, H., Fedorova, N., Tran, B., Russell, D., Berry, K., Utterback, T., Van Aken, S. E., Feldblyum, T. V., D’Ascenzo, M., Deng, W. L., Ramos, A. R., Alfano, J. R., Cartinhour, S., Chatterjee, A. K., Delaney, T. P., Lazarowitz, S. G., Martin, G. B., Schneider, D. J., Tang, X., Bender, C. L., White, O., Fraser, C. M., and Collmer, A. 2003. The complete genome sequence of the Arabidopsis and tomato pathogen Pseudomonas syringae pv. tomato DC3000. Proc. Natl. Acad. Sci. U.S.A. 100:10181-10186.

Chesnokova, O., Coutinho, J. B., Khan, I. H., Mikhail, M. S., and Kado, C. I. 1997. Characterization of flagella genes of Agrobacterium tumefaciens, and the effect of a bald strain on virulence. Mol. Microbiol. 23:579-590.

Cole, S. T., Brosch, R., Parkhill, J., Garnier, T., Churcher, C., Harris, D., Gordon, S. V., Eiglmeier, K., Gas, S., Barry, C. E., Tekaia, F., Badcock, K., Basham, D., Brown, D., Chillingworth, T., Connor, R., Davies, R., Devlin, K., Feltwell, T., Gentles, S., Hamlin, N., Holroyd, S., Hornsby, T., Jagels, K., Krogh, A., Mclean, J., Moule, S., Murphy, L., Oliver, K., Osborne, J., Quail, M. A., Rajandream, M.-A., Rogers, J., Rutter, S., Seeger, K., Skelton, J., Squares, R., Squares, S., Sulston, J. E., Taylor, K., Whitehead, S., and Barrell, B. G. 2000. Deciphering the biology of 
Mycobacterium tuberculosis from the complete genome sequence. Nature 393:537-544.

Cole, S. T., Eiglmeier, K., Parkhill, J., James, K. D., Thomson, N. R., Wheeler, P. R., Honoré, N., Garnier, T., Chircher, C., Harris, D., Mungall, K., Basham, D., Brown, D., Chillingworth, T., Connor, R., Davies, R.M., Devlin, K., Duthoy, S., Feltwell, T., Fraser, A., Hamlin, N., Holroyd, S., Hornsby, T., Jagels, K., Lacroix, C., Maclean, J., Moule, S., Murphy, L., Oliver, K., Quail, M. A., Rajandream, M.-A., Rutherford, K. M., Rutter, S., Seeger, K., Simon, S., Simmonds, M., Skelton, J., Squares, R., Squares, S., Stevens, K., Taylor, K., Whitehead, S., Woodward, J. R., and Barrell, B. G. 2001. Massive gene decay in the leprosy bacillus. Nature 409:1007-1011.

Collmer, A., and Keen, N. T. 1986. The role of pectic enzymes in plant pathogenesis. Annu. Rev. Phytopathol. 24:383-409.

da Silva, A. C., Ferro, J. A., Reinach, F. C. , Farah, C. S., Furlan, L. R., Quaggio, R. B., Monteiro-Vitorello, C. B., Van Sluys, M. A., Almeida, N. F., Alves, L. M., do Amaral, A. M., Bertolini, M. C., Camargo, L. E. A., Camarotte, G., Cannavan, F., Cardozo, J., Chambergo, F., Ciapina, L. P., Cicarelli, R. M., Coutinho, L. L., Cursino-Santos, J. R., El-Dorry, H., Faria, J. B., Ferreira, A. J., Ferreira, R. C., Ferro, M. I., Formighieri, E. F., Franco, M. C., Greggio, C. C., Gruber, A., Katsuyama, A. M. Kishi, L. T., Leite, R. P., Lemos, E. G., Lemos, M. V., Locali, E. C., Machado, M. A., Madeira, A. M., Martinez-Rossi, N. M., Martins, E. C., Meidanis, J., Menck, C. F., Miyaki, C. Y., Moon, D. H., Moreira, L. M., Novo, M. T., Okura, V. K., Oliveira, M. C., Oliveira, V. R., Pereira, H. A., Rossi, A. , Sena, J.A., Silva, C., de Souza, R. F., Spinola, L. A., Takita, M. A., Tamura, R. E., Teixeira, E. C., Tezza, R. I., Trindade dos Santos, M. , Truffi, D., Tsai, S. M., White, F. F., Setúbal, J. C., and Kitajima, J. P. 2002. Comparison of the genomes of two Xanthomonas pathogens with differing host specificities. Nature 417:459-463.

Davis, M. J., Gillaspie, A. G., Jr., Harris, R. W., and Lawson, R. H. 1980. Ratoon stunting disease of sugarcane: Isolation of the causal bacterium. Science 210:1365-1367.

Davis, M. J., Gillaspie, A. G., Vidaver, A. K., and Harris, R. W. 1984. Clavibacter: A new genus containing some phytopathogenic coryneform bacteria, including Clavibacter xyli subsp. xyli sp. nov., subsp. nov. and Clavibacter xyli subsp. cynodontis subsp. nov., pathogens that cause ratoon stunting disease of sugarcane and Bermuda grass stunting disease. Int. J. Sys. Bacteriol. 34:107-117.

Dean, J. L., and Davis, M. J. 1989. Yield losses caused by ratoon stunting disease of sugarcane in Florida. J. Am. Soc. Sugarcane Technol. 10:6672.

Dong, Z., McCully, M. E., and Canny, M. J. 1997. Does Acetobacter diazotrophicus live and move in the xylem of sugarcane stems? Anatomical and physiological data. Annals of Botany 80:147-158.

Dreier, J., Meletzus, D., and Eichenlaub, R. 1997. Characterization of the plasmid encoded virulence region pat-1 of phytopathogenic Clavibacter michiganensis subsp. michiganensis. Mol. Plant-Microbe Interact. 10:195-206.

Evtushenko, L., Dorofeeva, L., Subbotin, J., and Tiedje, J. 2000. Leifsonia poae gen. nov., sp. nov., isolated from nematode galls on Роа аппиа, and reclassification of Corynebacterium aquaticum Leifson 1962 as Leifsonia aquatica (ex Leifson 1962) gen. nov., nom. rev., comb. nov. and Clavibacter xyli Davis et al. 1984 with two subspecies as Leifsonia xyli (Davis et al. 1984) gen. nov., com. nov. Int. J. Syst. Evol. Microbiol. 50:371-380.

Fang, F. C. 1997. Perspectives series: Host/pathogen interactions. J. Clin. Invest. 99:2818-2825

Fegan, M., Croft B. J., Teakle, D. S., Hayward, A. C., Smith, G. R. 1998. Sensitive and specific detection of Clavibacter xyli subsp. xyli, causal agent of ratoon stunting disease of sugarcane, with a polymerase chain reaction-based assay. Plant Pathol. 47:495-504.

Folcher, M., Gaillard, H., Nguyen, L. T., Lacroix, P., Bamas-Jacques, N., Rinkel, M., Thompson, C. J. 2001. Pleiotropic functions of a Streptomyces pristinaespiralis auto regulator receptor in development, antibiotic biosynthesis, and expression of a superoxide dismutase. J. Biol. Chem. 276:44297-44306.

Gallio, M., Sturgill, G., Rather, P., and Kylsten, P. 2002. A conserved mechanism for extra cellular signaling in eukaryotes and prokaryotes. Proc. Natl. Acad. Sci. U.S.A. 99:12208-12213.

Ghelardi, E., Celandroni, F., Beecher, D. J., Gominet, M., Lereclus, D., Wong, A. C., and Senesi, S. 2002. Requirement of flhA for swarming differentiation, flagellin export, and secretion of virulence-associated protein in Bacillus thuringiensis .J. Bacteriol. 184:6424-6433.

Gillaspie, A. G., and Teakle, D. S. 1989. Ratoon stunting disease. Pages 59-80 in: Diseases of Sugarcane: Major Diseases. C. Ricaud, B. T. Egan, A. G. Gillaspie, Jr., and C. G. Hughes, eds. Elsevier Science Publishing, Inc., New York.

Gobert, A. P., McGee, D. J., Akhtar, M., Mendz, G. L., Newton, J. C., Cheng, Y., Mobley, H. L., and Wilson, K. T. 2001. Helicobacter pylori arginase inhibits nitric oxide production by eukaryotic cells: A strategy for bacterial survival. Proc. Natl. Acad. Sci. U.S.A. 20:13844-13849.

Ichinose, Y., Shimizu, R., Ikeda, Y., Taguchi, F., Marutani, M., Mukaihara, T., Inagaki, Y., Toyoda, K., and Shiraishi, T. 2003. Need for flagella for complete virulence of Pseudomonas syringae pv. tabaci: Genetic analysis with flagella-defective mutants $f l i \mathrm{C}$ and $f l i \mathrm{D}$ in host tobacco plants. J. Gen. Plant Pathol. 69:244-249.

Jahr, H., Dreier, J., Meletzus, D., Bahro, R., and Eichenlaub, R. 2000. The endo- $\beta-1,4$-glucanase celA of Clavibacter michiganensis subsp. michiganensis is a pathogenicity determinant required for induction of bacterial wilt of tomato. Mol. Plant-Microbe Interact. 13:703-714.

Janssen, P. H, Yates, P. S., Grinton, B. E., Taylor, P. M., and Sait, M. 2002. Improved culturability of soil bacteria and isolation in pure culture of novel members of the divisions Acidobacteria, Actinobacteria, Proteobacteria, and Verrucomicrobia. Appl. Environ. Microbiol. 68:2391-2396.

Kao, J., and Damann, K. E. 1978. Microcolonies of the bacterium associated with ratoon stunting disease found in sugarcane xylem matrix. Phytopathology 68:545-551.

Karlin, S, Campbell, A.M., Mrazec, J. 1998. Analysis across diverse genomes. Annu. Rev. Genet. 32:185-225

Kende, H., and Zeevaart, J. A. D. 1997. The five "classical" plant hormones. Plant Cell 9:1197-1210.

Laine, M. J., Haapalainen, M., Wahlroos, T., Kankare, K., Nissinen, R., Kassuwi, S., and Metzler, M. C. 2000. The cellulase encoded by the native plasmid of Clavibacter michiganensis subsp. sepedonicus plays a role in virulence and contains an expansin-like domain. Physiol. Mol. Plant Pathol. 57:221-233.

Leifson, E. 1962. The bacterial flora of distilled and stored water. III. New species of the genera Corynebacterium, Flavobacterium, Spirillum and Pseudomonas. Int. Bull. Bacteriol. Nomencl. Taxon. 12:161-170.

Madden, J. C., Ruiz, N., and Caparon, M. 2001. Cytolysin-mediated translocation (CMT): A functional equivalent of type III secretion in grampositive bacteria. Cell 104:143-152.

Magarey, R. C., Suma, S., Irawan, Kuniata, L. S., and Allsopp, P. G. 2002. Diseases and pests encountered during a survey of Saccharum germplasm 'in the wild' in Papua New Guinea. Proc. Aust. Soc. Sugar Cane Technol. 24:219-227.

Matsumoto, H., Muroi, H., Umehara, M., Yoshitake, Y., and Tsuyumu, S. 2003. Peh production, flagellum synthesis, and virulence reduced in Erwinia carotovora subsp. carotovora by mutation in a homologue of cytR. Mol. Plant-Microbe Interact. 16:389-397.

Metzler, M. C., Laine, M. J., and De Boer, S. H. 1997. The status of molecular biological research on the plant pathogenic genus Clavibacter. FEMS (Fed. Eur. Microbiol. Soc.) Lett. 150:1-8.

Mills, L., Leaman, T. M., Taghavi, S. M., Shackel, L., Dominiak, B. C. Taylor, P. W. J., Fegan, M., and Teakle, D. S. 2001. Leifsonia xyli-like bacteria are endophytes of grasses in eastern Australia. Aust. Plant Pathol. 30:145-151.

Moran, N. 2002. Microbial minimalism: Genome reduction in bacterial pathogens. Cell 108:583-586.

Okinaka, Y., Yang, C. H., Perna, N., and Keen, N. T. 2002. Microarray profiling of Erwinia chrysanthemi 3937 genes that are regulated during plant infection. Mol. Plant-Microbe Interact. 15:619-629.

Omura, S., Ikeda, H., Ishikawa, J., Hanamoto, A., Takahashi, C., Shinose, M., Takahashi, Y., Horikawa, H., Nakazawa, H., Osonoe, T., Kikuchi, H., Shiba, T., Sakaki, Y., and Hattori, M. 2001. Genome sequence of an industrial microorganism Streptomyces avermitilis: Deducing the ability of producing secondary metabolites. Proc. Natl. Acad. Sci. U.S.A. 21:12215-12220.

Parkhill, J., Wren, B. W., Thomson, N. R., Titball, R. W., Holden, M. T. G., Prentice, M. B., Sebaihia, M., James, K. D., Churcher, C., Mungall, K. L., Baker, S., Basham, D., Bentley, S. D., Brooks, K., CerdenoTarraga, A. M., Chillingworth, T., Cronin, A., Davies, R. M., Davis, P., Dougan, G., Feltwell, T., Hamlin, N., Holroyd, S., Jagels, K., Karlyshev, A. V., Leather, S., Moule, S., Oyston, P. C., Quail, M., Rutherford, K., Simmonds, M., Skelton, J., Stevens, K., Whitehead, S., and Barrell, B. G. 2001. Genome sequence of Yersinia pestis, the causative agent of plague. Nature 413:523-527.

Purcell, A. H., and Hopkins, D. L. 1996. Fastidious xylem-limited bacterial plant pathogens. Annu. Rev. Phytopathol. 34:131-151.

Raoult, D., Ogata, H., Audic, S., Robert, C., Suhre, K., Drancourt, M., and Claverie, J. 2003. Tropheryma whipplei twist: A human pathogenic Actinobacteria with a reduced genome. Genome Res. 13:1800-1809.

Reddy, G. S. N., Prakash, J. S. S., Srinivas, R., Matsumoto, G. I., and Shivaji, S. 2003. Leifsonia rubra sp. nov. and Leifsonia aurea sp. nov., psychrophiles from a pond in Antarctica. Int. J. Syst. Evol. Microbiol. 53:977-984.

Rott, P., Davis, M. J., and Baudin, P. 1994. Serological variability in Xanthomonas albilineans, causal agent of leaf scald disease of sugarcane. Plant Pathol. 43:344-349. 
Schell, M. A., Karmirantzou, M., Snel, B., Vilanova, D., Berger, B., Pessi, G., Zwahlen, M. C., Desiere, F., Bork, P., Delley, M., Pridmore, R. D., and Arigoni, F. 2002. The genome sequence of Bifidobacterium longum reflects its adaptation to the human gastrointestinal tract. Proc. Natl. Acad. Sci. U.S.A. 99:14422-14427.

Seshadri, R., Paulsen, I. T., Eisen, J. A., Read, T. D., Nelson, K. E., Nelson, W. C., Ward, N. L., Tettelin, H., Davidsen, T. M., Beanan, M. J., Deboy, R. T., Daugherty, S. C., Brinkac, L. M., Madupu, R., Dodson, R. J., Khouri, H. M., Lee, K. H., Carty, H. A., Scanlan, D., Heinzen, R. A., Thompson, H. A., Samuel, J. E., Fraser, C. M., and Heidelberg, J. F. 2003. Complete genome sequence of the Q-fever pathogen Coxiella burnetii. Proc. Natl. Acad. Sci. U.S.A. 100:54555460.

Simpson, A. J. G., Reinach, F. C., Arruda, P., Abreu, F. A., Acencio, M., Alvarenga, R., Alves, L. M. C., Araya, J. E., Baia, G. S., Baptista, C. S., Barros, M. H., Bonaccorsi, E. D., Bordin, S., Bove, J. M., Briones, M. R., Bueno, M. R., Camargo, A. A., Camargo, L. E. A., Carraro, D. M., Carrer, H., Colauto, N. B., Colombo, C., Costa, F. F., Costa, M. C., Costa-Neto, C. M., Coutinho, L. L., Cristofani, M., Dias-Neto, E., Docena, C., El-Dorry, H., Facincani, A. P., Ferreira, A. J., Ferreira, V. C., Ferro, J. A., Fraga, J. S., Franca, S. C., Franco, M. C., Frohme, M., Furlan, L. R., Garnier, M., Goldman, G. H., Goldman, M. H., Gomes, S. L., Gruber, A., Ho, P. L., Hoheisel, J. D., Junqueira, M. L., Kemper, E. L., Kitajima, J. P., Krieger, J. E., Kuramae, E. E., Laigret, F., Lambais, M. R., Leite, L. C., Lemos, E. G., Lemos, M. V., Lopes, S. A., Lopes, C. R., Machado, J. A., Machado, M. A., Madeira, A. M., Madeira, H. M., Marino, C. L., Marques, M. V., Martins, E. A., Martins, E. M., Matsukuma, A. Y., Menck, C. F., Miracca, E. C., Miyaki, C. Y., Monteiro-Vitorello, C. B., Moon, D. H., Nagai, M. A., Nascimento, A. L., Netto, L. E., Nhani, A. Jr., Nóbrega, F. G., Nunes, L. R., Oliveira, M. A., de Oliveira, M. C., de Oliveira, R. C., Palmieri, D. A., Paris, A., Peixoto, B. R., Pereira, G. A., Pereira, H. A. Jr., Pesquero, J. B., Quaggio, R. B., Roberto, P. G., Rodrigues, V., de M. Rosa, A. J., de Rosa, V. E. Jr., de Sa, R. G., Santelli, R. V., Sawasaki, H. E., da Silva, A. C., da Silva, A. M., da Silva, F. R., da Silva, W. A. Jr., da Silveira, J. F., Silvestri, M. L., Siqueira, W. J., de Souza, A. A., de Souza, A. P., Terenzi, M. F., Truffi, D., Tsai, S. M., Tsuhako, M. H., Vallada, H., Van Sluys, M. A., Verjovski-Almeida, S., Vettore, A. L., Zago, M. A., Zatz, M., Meidanis, J., and Setúbal, J. C. 2000. The genome sequence of the plant pathogen Xylella fastidiosa. Nature 406:151-157

Suzuki, K., Suzuki, M., Sasaki, J., Park, Y. H., and Komagata, K. 1999. Leifsonia gen. nov., a genus for 2,4-diaminobutyric acid-containing actinomycetes to accommodate Corynebacterium aquaticum Leifson 1962 and Clavibacter xyli subsp. cynodontis Davis et al. 1984. J. Gen. Appl. Microbiol. 45:253-262.

Taguchi, F., Shimizu, R., Inagaki, Y., Toyoda, K., Shiraishi, T., and Ichinose, Y. 2003. Post-translational modification of flagellin determines the specificity of HR induction. Plant Cell Physiol. 44:342-349.
Tans-Kersten, J., Huang, H., and Allen, C. 2001. Ralstonia solanacearum needs motility for invasive virulence on tomato. J. Bacteriol. 183:35973605.

Teakle, D. S., Appleton, J. M., and Steindl, D. R. 1978. An anatomical basis for resistance of sugarcane to ratoon stunting disease. Physiol. Plant Pathol. 12:83-91

Van Sluys, M. A., Monteiro-Vitorello, C. B., Camargo, L. E. A., Menck, C. F., da Silva, A. C. R., Ferro, J. A., Oliveira, M. C., Setubal, J. C., Kitajima, J. P., and Simpson, A. J. 2002. Comparative genomic analysis of plant-associated bacteria. Annu. Rev. Phytopathol. 40:169-189.

Van Sluys, M. A., de Oliveira, M. C., Monteiro-Vitorello, C. B., Miyaki, C. Y., Furlan, L. R., Camargo, L. E. A., da Silva, A. C., Moon, D. H., Takita, M. A., Lemos, E. G., Machado, M. A., Ferro, M. I., da Silva, F R., Goldman, M. H., Goldman, G. H., Lemos, M. V., El-Dorry, H., Tsai, S. M., Carrer, H., Carraro, D. M., de Oliveira, R. C., Nunes, L. R., Siqueira, W. J., Coutinho, L. L., Kimura, E. T., Ferro, E. S., Harakava, R., Kuramae, E. E., Marino, C. L., Giglioti, E., Abreu, I. L., Alves, L. M., do Amaral, A. M., Baia, G. S., Blanco, S. R., Brito, M. S., Cannavan, F. S., Celestino, A. V., da Cunha, A. F., Fenille, R. C., Ferro, J. A., Formighieri, E. F., Kishi, L. T., Leoni, S. G., Oliveira, A. R., Rosa, V. E. Jr., Sassaki, F. T., Sena, J. A., de Souza, A. A., Truffi, D. Tsukumo, F., Yanai, G. M., Zaros, L. G., Civerolo, E. L., Simpson, A. J., Almeida, N. F. Jr., Setúbal, J. C., and Kitajima, J. P. 2003. Comparative analyses of the complete genome sequences of Pierce's disease and citrus variegated chlorosis strains of Xylella fastidiosa. J. Bacteriol. 185:1018-1026.

Weaver, L., Teakle, D. S., and Hayward, A. C. 1977. Ultrastructural studies on the bacterium associated with the ratoon stunting disease of sugarcane. Aust. J. Agric. Res. 28:843-852.

Wood, D. W., Setubal, J. C., Kaul, R., Monks, D. E., Kitajima, J. P., Okura, V. K., Zhou, Y., Chen, L., Wood, G. E., Almeida, N. F. Jr, Woo, L., Chen, Y., Paulsen, I. T., Eisen, J. A., Karp, P. D., Bovee, D. Sr., Chapman, P., Clendenning, J., Deatherage, G., Gillet, W., Grant, C., Kutyavin, T., Levy, R., Li, M. J., McClelland, E., Palmieri, A., Raymond, C., Rouse, G., Saenphimmachak, C., Wu, Z., Romero, P., Gordon, D., Zhang, S., Yoo, H., Tao, Y., Biddle, P., Jung, M., Krespan, W., Perry, M., Gordon-Kamm, B., Liao, L., Kim, S., Hendrick, C., Zhao, Z. Y., Dolan, M., Chumley, F., Tingey, S. V., Tomb, J. F., Gordon, M. P., Olson, M. V., and Nester, E. W. 2001. The genome of the natural genetic engineer Agrobacterium tumefaciens C58. Science, 294:2317-2323.

\section{AUTHOR-RECOMMENDED INTERNET RESOURCES}

The Agronomical and Environmental Genomes Consortium website: aeg.lbi.ic.unicamp.br

The Biological Institute Culture Collection of Phytopathogenic Bacteria website: wdcm.nig.ac.jp

Yale University Gerstein Lab Pseudogenes and Intergenic Analyses website: bioinfo.mbb.yale.edu/genome/pseudogene 